\title{
CALIX[4]ARENE CHALCONE AMIDES EFFECTS ON MYOMETRIUM MITOCHONDRIA
}

\author{
S. G. SHLYKOV ${ }^{\bowtie}$, A. M. KUSHNAROVA-VAKAL', A. V. SYLENKO', \\ L. G. BABICH', O. YU. CHUNIKHIN', O. A. YESYPENKO', \\ V. I. KALCHENKO', S. O. KOSTERIN ${ }^{1}$
}

\author{
${ }^{1}$ Palladin Institute of Biochemistry, National Academy of Sciences of Ukraine, Kyiv; \\ 凶e-mail: sshlykov@biochem.kiev.ua; \\ ${ }^{2}$ Institute of Organic Chemistry, National Academy of Sciences of Ukraine, Kyiv
}

Received: 19 November 2018; Accepted: 14 March 2019

\begin{abstract}
Mitochondria are a key player in a wide range of the most important functions of the cell. Calixarenes are supramolecular compounds that have been widely used in bioorganic chemistry and biochemistry. The aim of this work was to study the effects of calix[4]arenes with two (C-1012, C-1021), three (C-1023, C-1024) and four (C-1011) chalcone amide groups on the myometrial mitochondria membranes polarization, $\mathrm{Ca}^{2+}$ concentration in the matrix of these organelles $\left(\left[\mathrm{Ca}^{2+}\right]_{m}\right)$ and on the average hydrodynamic diameter of mitochondria. It was shown that permeabilized myometrium cells incubation with calix[4]arenes containing two or more chalcone amide groups, was accompanied by an increased level of myometrial mitochondria membranes polarization. All studied calix[4]arenes increased $\left[\mathrm{Ca}^{2+}\right]_{m}$ values in the absence and in the presence of exogenous $\mathrm{Ca}^{2+}$. The values of $\left[\mathrm{Ca}^{2+}\right]_{m}$ in the absence of exogenous $\mathrm{Ca}^{2+}$ were higher at mitochondria incubation in $\mathrm{Mg}^{2+}$-containing, than in $\mathrm{Mg}^{2+}, A T P$-containing medium. Incubation of isolated mitochondria with the studied calix[4]arenes resulted in changes of mitochondria volume: at incubation with C-1012, C-1021, C-1023 the average hydrodynamic diameter was decreased, while with C-1011 it was increased. Thus, we have shown that a short-term (5 min) incubation of mitochondria in the presence of $10 \mu \mathrm{M}$ calix[4]arenes, which contain from two to four chalcone amide groups, increased the level of mitochondria membranes polarization, ionized Ca concentration in the matrix and had different effects on the mitochondrial volume.
\end{abstract}

Keywords: myometrium, mitochondria, $\left[\mathrm{Ca}^{2+}\right]_{m}, \mathrm{Mg}^{2+}$, ATP, calix[4]arene chalcone amides.

$\mathrm{M}$ itochondria play a significant role in a wide range of the most important functions of the cell, such as $\mathrm{Ca}^{2+}$ signaling, apoptosis, adaptation to stress, steroidogenesis, and aging [1, 2]. Disruption of the mitochondria functioning is a key element in age-dependent diseases, neurodegenerative disorders and various forms of cancer [2]. Channels and transporters of ions and metabolites through the mitochondrial membrane were directly involved in the regulation of mitochondrial functions and control of the cell metabolism. The capacity of the mitochondria to accumulate the $\mathrm{Ca}^{2+}$ is known from 60 years of XX century [3], but the molecular mechanisms and significance of the $\mathrm{Ca}^{2+}$ accumulation in the mitochondria have been clarified much later [4]. An increase in ionized $\mathrm{Ca}$ concentration in the mitochondria matrix is accompanied by two opposite effects. On the one hand, $\mathrm{Ca}^{2+}$ activation of mitochondrial metabolism through stimulation of the Krebs cycle and the activity of the respiratory chain leads to an increase in the synthesis of the ATP. On the other hand, mitochondria $\mathrm{Ca}^{2+}$ overloading leads to the opening of the mitochondrial permeability transition pore, the release of cytochrome c, and as a result, cell death [4]. So searching compounds that can affect the exchange and $\mathrm{Ca}^{2+}$ concentration in the mitochondria matrix is a strategic task of modern biochemistry.

The level of mitochondria membranes polarization is an important parameter in their functioning most transport processes in these organelles are potential-dependent. In particular, mitochondrial $\mathrm{Ca}^{2+}$

(c) 2019 Shlykov S. G. et al. This is an open-access article distributed under the terms of the Creative Commons Attribution License, which permits unrestricted use, distribution, and reproduction in any medium, provided the original author and source are credited. 
transporting systems are potential-dependent [5-7]. Consequently, affecting the level of mitochondrial membranes polarization could regulate the $\mathrm{Ca}^{2+}$ concentration in the mitochondria matrix.

Calixarenes represent supramolecular compounds with a unique three-dimensional structure that can be easily functionalized with different chemical groups at either the upper or lower rim. Calixarenes have been used as important tools for investigations in bioorganic chemistry and biochemistry [1, 8-11]. Why are calixarenes so widely investigated and used? Firstly, due to its hydrophobic properties, they are able to dissolve in cell lipids, which provide them with the role of biologically active compounds carriers. Secondly, there is the possibility to bind to calixarenes functionally active groups in varying quantities. Chalcone amides, members of flavonoids, have a wide range of biological activity [12-16]. This led to a great interest of researchers in exploring the possibility of chalcones using as pharmaceutical preparations at various pathological conditions [12-14, 17].

In previous works, we showed that calix[4]arene chalcone amides (named C-136, C-137 and C-138) were able to influence on the level of mitochondria membrane polarization [1] and $\mathrm{Ca}^{2+}$ concentration in the myometrial mitochondria matrix [10]. Experiments were conducted using calix[4]arenes C-136 and $\mathrm{C}-137$, that possess two chalcone amide moieties at the lower rim and the calix[4]arene C-138 with one such group. Naturally raised the question of whether to increase the effect of calix[4]arene on the investigated processes with the change of the relative location of the chalcone amide groups and/ or increasing their number at the calix[4]arene lower rim.

Thus, the aim of this work was to continue the study of the calix[4]arene chalcone amides effects on the myometrial mitochondria membranes polarization level, $\mathrm{Ca}^{2+}$ concentration in the matrix of these organelles and on the average hydrodynamic diameter of mitochondria. Calix[4]arenes with two (C-1012 and C-1021), three (C-1023 and C-1024) and four (C-1011) chalcone amide groups were studied. The structural formulae of investigated calix[4]arenes are presented in Fig. 1.

\section{Materials and Methods}

Calix[4]arene chalcone amides were synthesized by the previously described scheme [18] from the corresponding ethyl esters. At the first stage, the esters were hydrolyzed in the alkaline medium to carboxylic acids, which were converted to chlorides by the reaction with chloride oxalyl in dry chloroform. The interaction of the latter with 4'-aminochalcone in the presence of triethylamine led to the target calixarene chalcone amides. The pure products were isolated at $60-75 \%$ yield after column chromatography. Such esters were used as starting materials: 25,26,27,28-tetra (ethoxycarbonylmethoxy)calix[4]arene[18] for the preparation of C-1011, 25,26-dipropoxy-27,28-bis(ethoxycarbonylmethoxy)calix[4]arene[19] - for C-1012, 25,27-dipropoxy-26,28bis(ethoxycarbonylmethoxy)calix[4]arene[19] - for C-1021, 25-hydroxy-26,27,28-tri(ethoxycarbonylmethoxy)calix[4]arene[18] - for C-1023 and 25-propoxy-26,27,28-tri(ethoxycarbonylmethoxy)calix[4]arene[18] - for C-1024.

The effects of calix[4]arenes C-136 and C-137, which contain two distal-placed chalcone groups, were presented in the previous papers $[1,10]$. In the C-137 structure, two other phenolic hydroxyls remain free, whereas in compound C-136 they are replaced by propyl groups.

The calix[4]arene C-1021 is an analogue of the C-136 compound, but has nitro groups $\left(-\mathrm{NO}_{2}\right)$ in the para-position of the terminal phenyl rings.

The calix[4]arene C-1012 also has two chalcone groups, but they are located proximally. Two other hydroxyls are replaced by propyl groups.

The calix[4]arenes C-1023 and C-1024 contain three chalcone groups. In the molecule C-1023 the hydroxyl group remains free, and in C-1024 it is replaced by propyl group.

The calix[4]arene C-1011 has four chalcone groups.

All manipulations with animals were carried out according to "European Convention for the Protection of Vertebrate Animals used for Experimental and Other Scientific Purposes" and the law of Ukraine "On protection of animals from cruelty". Rats were kept under the stationary vivarium conditions at the constant temperature and basic allowance. Animals were narcotized with chloroform and then sacrificed using cervical dislocation. The uterus was eliminated rapidly. All procedures were executed separately from the other rats.

Experiments were conducted on two biochemical models: isolated myometrial mitochondria and permeabilized myometrial cells.

Nonpregnant rat myometrium mitochondria were isolated using a differential centrifugation 
A

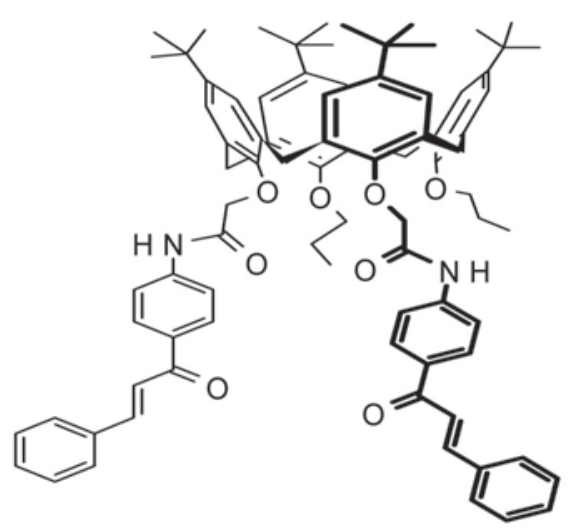

C-1012

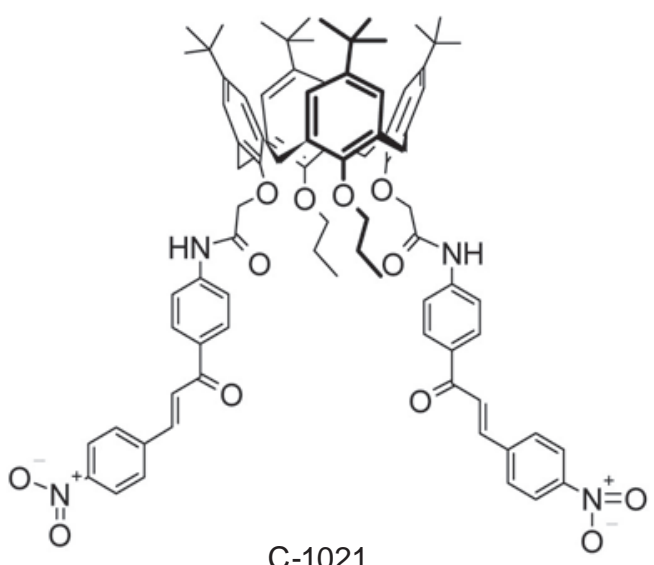

B

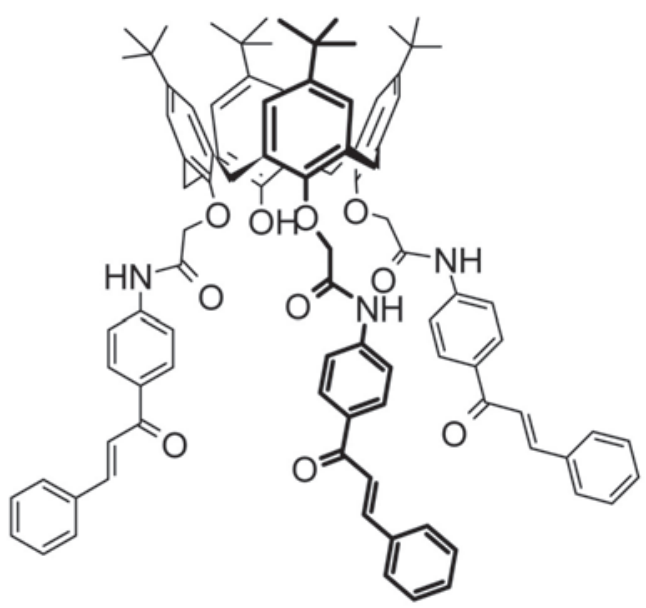

C-1021

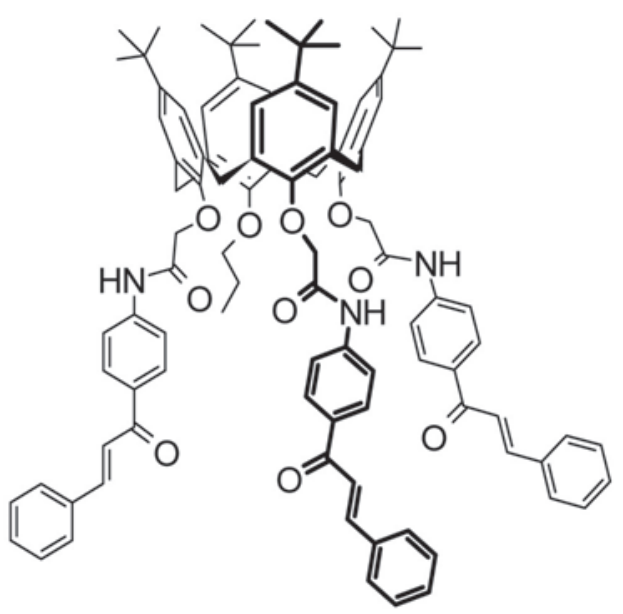

C-1024

C

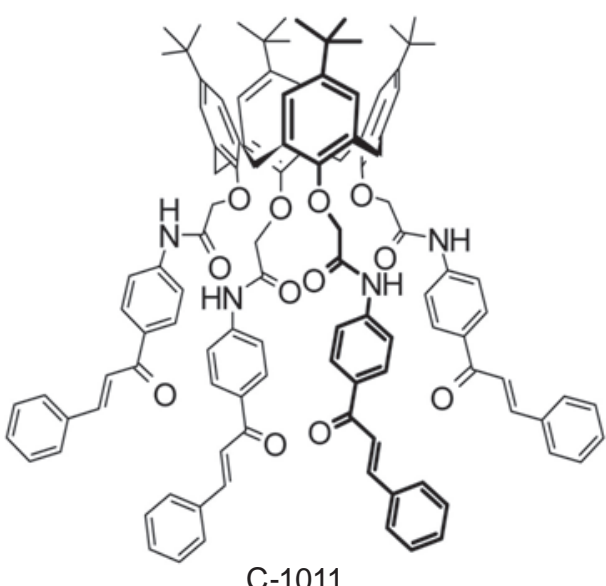

Fig. 1. Calix[4]arene chalcone amides structural formulae: $\boldsymbol{A}$ - two, $\boldsymbol{B}$ - three, $\boldsymbol{C}$ - four chalcone amide groups

method [20]. The obtained preparation was suspended in a solution (at $4{ }^{\circ} \mathrm{C}$ ) with the following composition $(\mathrm{mM})$ : sucrose - 250, EGTA - 1, Hepes - 20; $\mathrm{pH}$ 7.4. The protein concentration of the mitochondria fraction was determined by Bradford assay [21].
The concentration of the mitochondrial protein in the sample was $25 \mu \mathrm{g} / \mathrm{ml}$.

Nonpregnant rat myometrium cell suspension was isolated using collagenase method [22]. 
The polarization of mitochondria membranes was investigated using potential sensitive probe $0.1 \mu \mathrm{M}$ TMRM (tetramethylrhodamine-methyl-ester, $\left.\lambda_{\text {exc }}=540 \mathrm{~nm}, \lambda_{\text {em }}=590 \mathrm{~nm}\right)$ and COULTER EPICS XL ${ }^{\mathrm{TM}}$ flow cytometry (Beckman Coulter). The studies were carried out in a medium containing (mM): $\mathrm{KCl}-125, \mathrm{NaCl}-25, \mathrm{~K}^{+}$-phosphate buffer 2 , sodium succinate -5 , Hepes $-20 ; \mathrm{pH}$ 7.4. Digitonin $(0.1 \mathrm{mg} / \mathrm{ml})$ was added to each sample tube in order to permeabilize cell plasma membranes. Cells suspension was incubated with $0.1 \mu \mathrm{M}$ TMRM at room temperature during $5 \mathrm{~min}$ and the distribution of fluorescent due was analyzed immediately. Each estimation was the average fluorescence intensity of 10000 events. The data were presented in arbitrary units that were calculated as "average fluorescence intensity of the sample" minus "average fluorescence intensity of the sample after $1 \mu \mathrm{M}$ CCCP addition".

Changes in the ionized calcium concentration in the mitochondria from rat myometrium were investigated using the QuantaMaster ${ }^{\mathrm{TM}} 40$ spectrofluorimeter (Photon Technology International) and the fluorescent probe Fluo $4 \mathrm{AM}\left(\lambda_{\text {exc }}=490 \mathrm{~nm}\right.$, $\left.\lambda_{\mathrm{em}}=520 \mathrm{~nm}\right)$. Myometrium mitochondria were loaded with $2 \mu \mathrm{M}$ Fluo $4 \mathrm{AM}$ for $30 \mathrm{~min}$ at $37^{\circ} \mathrm{C}$ in a medium with following composition (mM): sucrose - 250, EGTA - 1, Hepes - 20, pH 7.4. Thereafter, the suspension of mitochondria was diluted $(1: 10)$ by the same medium containing no fluorescence probe followed by centrifugation. The pellet was resuspended in the same medium containing no fluorescence probe. The studies were carried out in a medium containing $(\mathrm{mM})$ : sucrose $-250, \mathrm{~K}^{+}-$ phosphate buffer -2 , sodium succinate $-5, \mathrm{MgCl}_{2}-$ $3, \pm \mathrm{ATP}-3, \pm \mathrm{CaCl}_{2}-0.1$, Hepes -20 ; pH 7.4. The concentration of the mitochondrial protein in the sample was $25 \mu \mathrm{g} / \mathrm{ml}$. The testing of each sample was completed by adding $0.1 \%$ Triton X-100 and, in 1 min, 5 mM EGTA (fluorescence intensities $\mathrm{F}_{\text {max }}$ and $\mathrm{F}_{\min }$, respectively). The concentration of ionized $\mathrm{Ca}$ in the mitochondria matrix was calculated using the Grynkiewicz equation [23]. The concentration of calix[4]arenes in the sample was $10 \mu \mathrm{M}$.

The hydrodynamic diameter of mitochondria was investigated using the dynamic light scattering method. The studies were carried out in the same medium as it was for the ionized calcium concentration testing. Isolated mitochondria were incubated without (control) or with studied calix[4]arenes during 5 min and after this hydrodynamic diameter was tested.
In the study the following reagents were used: EGTA, Hepes, trifluoperazine, protonophore CCCP, $\mathrm{D}(+)$-sucrose, ATP, (Sigma, USA); $\mathrm{Ca}^{2+}$-sensitive probe Fluo 4AM, potential-sensitive probe TMRM (Invitrogen, USA); digitonin (Merck, Germany) and other chemicals of domestic production of analytical or reagent grades.

\section{Results and Discussion}

The polarization of mitochondria membranes was investigated using potential sensitive probe TMRM and flow cytometry. The cell suspension was incubated in the standard medium containing 0.01\% digitonin. Permeabilization of the plasma membrane with digitonin excludes the contribution of its polarization to the probe signal and it ensures the entrance of the medium components into cells. As can be seen from Fig. 2, autofluorescence of cells could be recorded upon their introduction into the incubation medium (Fig. 2, blue line). Then, cells incubation with fluorescence dye TMRM leads to an increase in the fluorescence intensity, which is evidenced by the right-hand shift of the signal (Fig. 2, red line). So, accumulation of the positively charged probe in mitochondria was observed which evidenced polarization of the internal membrane of these organelles. Further introduction of CCCP into the incubation medium with cells loaded with TMRM led to a decrease in the fluorescence intensity, which evidenced exit of the probe from mitochondria due to membrane depolarization (Fig. 2, green line).

The influence of calix[4]arenes with two (C-1012 and C-1021), three (C-1023 and C-1024) and four (C-1011) chalcone amide groups on myometrial mitochondria membrane potential were studied. Myometrium cell suspension was preincubated with calix[4]arenes $(10 \mu \mathrm{M})$ for $5 \mathrm{~min}$ in the incubation medium (see Materials and methods section) in the presence of $0.1 \mathrm{mg} / \mathrm{ml}$ digitonin. In the case of control samples, the incubation was performed in the presence of dimethylformamide (DMF), calix[4]arenes solvent. The cell suspension was loaded with $100 \mathrm{nM}$ TMRM during the following $5 \mathrm{~min}$. As follows from the data presented in Fig. 3, myometrium cell incubation with $10 \mu \mathrm{M}$ calix[4]arenes led to an increase in mitochondrial membrane polarization.

In previous work, we showed that preliminary incubation of permeabilized myometrium cells with calix[4]arene C-138, which contains one chalcone amide group not affected the CCCP-sensitive component of the myometrial mitochondria membranes 


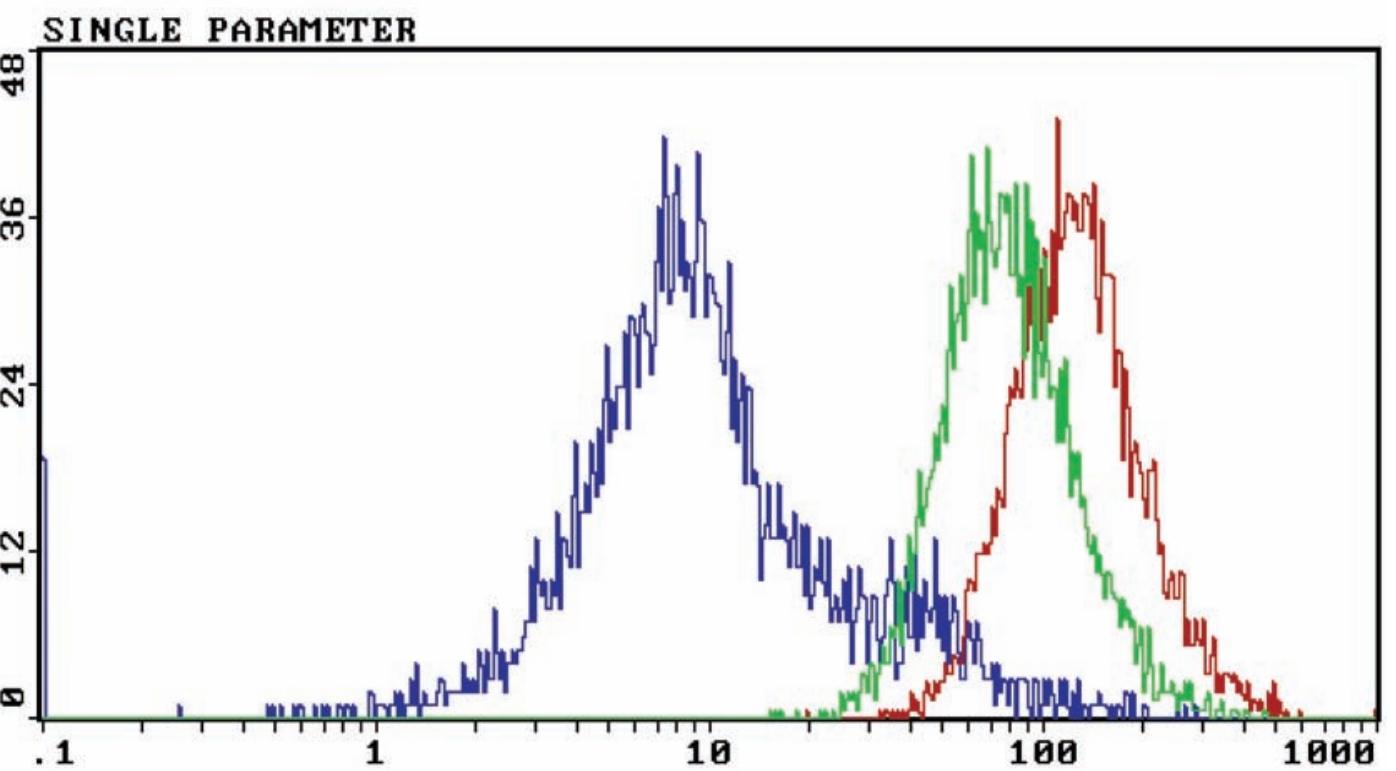

Fig. 2. Analysis of myometrium cell fluorescence intensity upon treatment with digitonin: blue - cell suspension autofluorescence; red - cell suspension + 100 nM TMRM; green - cell suspension + 100 nM TMRM + $1 \mu M$ CCCP. Axes: $x$, fluorescence intensity, $y$, number of events

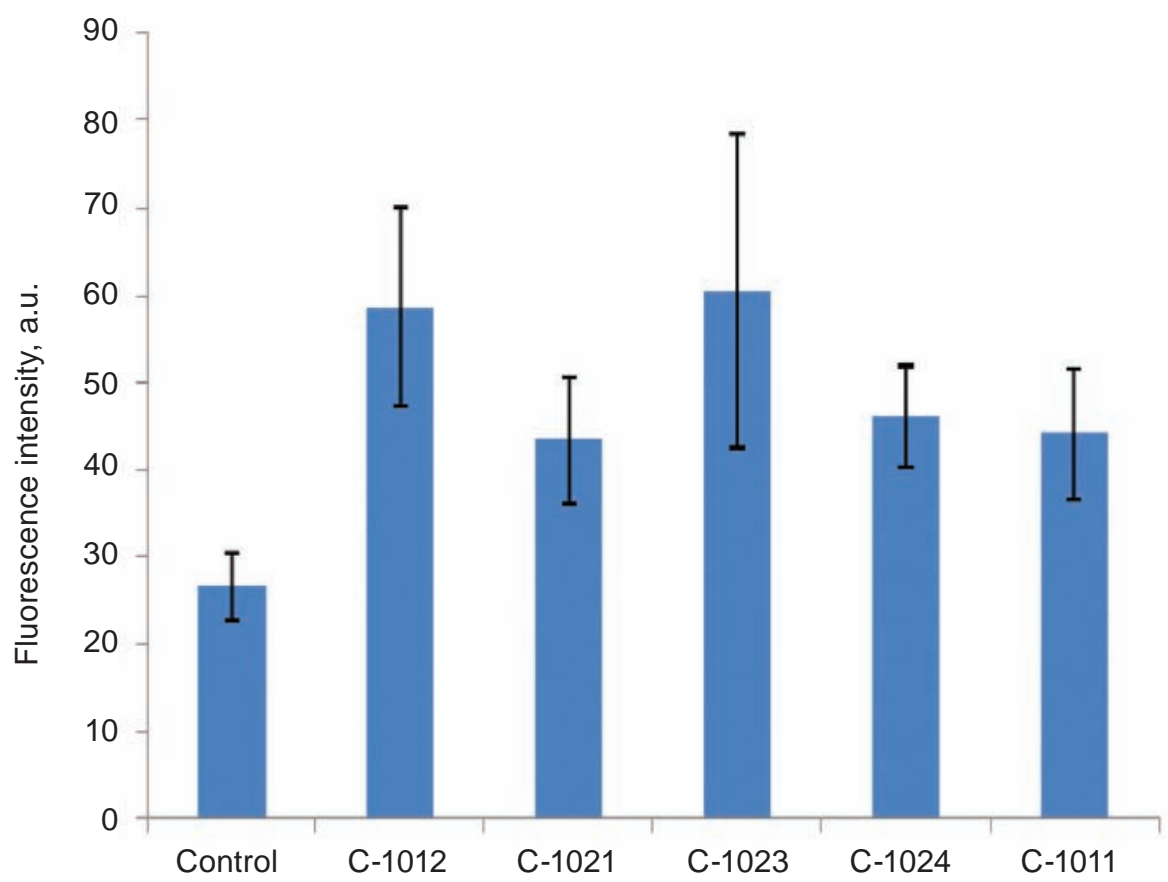

Fig. 3. The effect of calix[4]arenes C-1012, C-1021, C-1023, C-1024 and C-1011 on the fluorescence intensity of TMRM loaded into myometrium myocytes in the presence of $0.1 \mathrm{mg} / \mathrm{ml}$ digitonin $(M \pm m, n=7)$

polarization, whereas calix[4]arenes C-136, C-137 (containing two chalcone amide groups) increased the polarization of mitochondria membranes [1]. Now it was shown that all investigated calix[4]arenes (C-1012, C-1021, C-1023, C-1024 and C-1011) increased the level of mitochondria membranes po- larization, but this effect did not change with the increase in the number of chalcone amide groups and their relative position in the calix[4]arenes.

So, mitochondria incubation with calix[4]arenes containing two or more chalcone amide groups, accompanied by an increase in the level of myometrial 
mitochondria membranes polarization. The inner membranes potential is a key factor in the functioning of the mitochondria [24, 25]. In particular, it is shown that ATP synthesis, $\mathrm{K}$ and $\mathrm{Ca}$ ions transport depends on the level of mitochondrial membranes polarization. It is well known that mitochondria are able to accumulate a considerable amount of Ca ions $[26,27] . \mathrm{Ca}^{2+}$ accumulation in mitochondria depends on many factors, but the level of membranes polarization is one of the defining [26]. Earlier, using isotope technique $\left({ }^{45} \mathrm{Ca}^{2+}\right)$, we demonstrated that preliminary incubation of the digitonin-permeabilized myometrium cells with calix[4]arene chalcone amides led to protonophore-sensitive accumulation of Ca ions in mitochondria of the uterus smooth muscle [19]. It should be noted that the isotope technique allows registering the so-called total $\mathrm{Ca}^{2+}$ concentration, that is, ionized plus bound. However, functionally active is the ionized $\mathrm{Ca}$, which can be tested using fluorescent dyes.

Earlier we have shown that isolated mitochondria incubation with calix[4]arenes C-138 (one chalcone amide group) or C-136, C-137 (two chalcone amide groups) resulted in matrix $\mathrm{Ca}^{2+}$ concentration increasing [10]. Our next experiments were designed to study the impact of calix[4]arenes, which contain from 2 to 4 chalcone amide groups on the

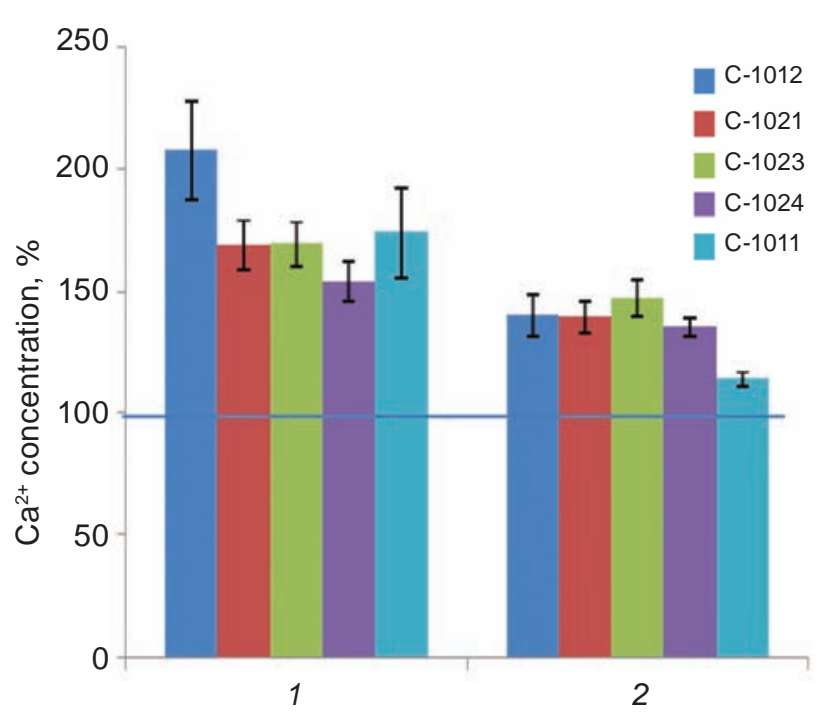

Fig. 4. $\left[\mathrm{Ca}^{2+}\right]_{m}$ values after 5 min mitochondria incubation in $\mathrm{Mg}^{2+}$-containing medium without (control $=100 \%$ ) or with $10 \mu \mathrm{M}$ calix [4] arenes in the $a b$ sence of exogenous $\mathrm{Ca}^{2+}$ (1) and $\left[\mathrm{Ca}^{2+}\right]_{m}$ values after next 5 min mitochondria incubation in the presence of $100 \mu M \mathrm{Ca}^{2+}(2) ;(M \pm m, n=6)$
$\mathrm{Ca}^{2+}$ concentration in the mitochondria matrix. The ionized calcium concentration in the mitochondria $\left(\left[\mathrm{Ca}^{2+}\right]_{\mathrm{m}}\right)$ from rat myometrium was investigated using the fluorescent probe Fluo 4AM. Mitochondria, loaded with a fluorescent probe, were incubated without (control) or with $10 \mu \mathrm{M}$ calix[4]arenes during 5 min in $\mathrm{Mg}^{2+}$ - or $\mathrm{Mg}^{2+}$,ATP-containing medium in the absence of exogenous $\mathrm{Ca}^{2+}$. As we have shown previously, ATP addition to the $\mathrm{Mg}^{2+}$-containing medium resulted in $\left[\mathrm{Ca}^{2+}\right]_{\mathrm{m}}$ (in the absence of exogenous $\mathrm{Ca}^{2+}$ ) [28] and total $\mathrm{Ca}^{2+}$ accumulation increase [27]. The results of each experiment were normalized to $100 \%$ of the control sample. As can be seen from the results shown in Fig. 4 (1) and Fig. 5 (1), all studied calix[4]arenes increased $\left[\mathrm{Ca}^{2+}\right]_{\mathrm{m}}$ values in the absence of exogenous $\mathrm{Ca}^{2+}$. It should be noted that $\left[\mathrm{Ca}^{2+}\right]_{\mathrm{m}}$ values were higher at mitochondria incubation in $\mathrm{Mg}^{2+}$ - than $\mathrm{Mg}^{2+}$,ATP-containing medium. Exogenous $\mathrm{Ca}^{2+}(100 \mu \mathrm{M})$ addition to the incubation medium resulted in an increase of $\left[\mathrm{Ca}^{2+}\right]_{\mathrm{m}}$ values of control samples (data not shown) and in all samples incubated with calix[4]arenes, as can be seen at Fig. 4 (2) and Fig. 5 (2).

It was also shown that isolated mitochondria incubation with studied calix[4]arenes resulted in changes of mitochondria volume: average hydrodynamic diameter decreased at incubation with

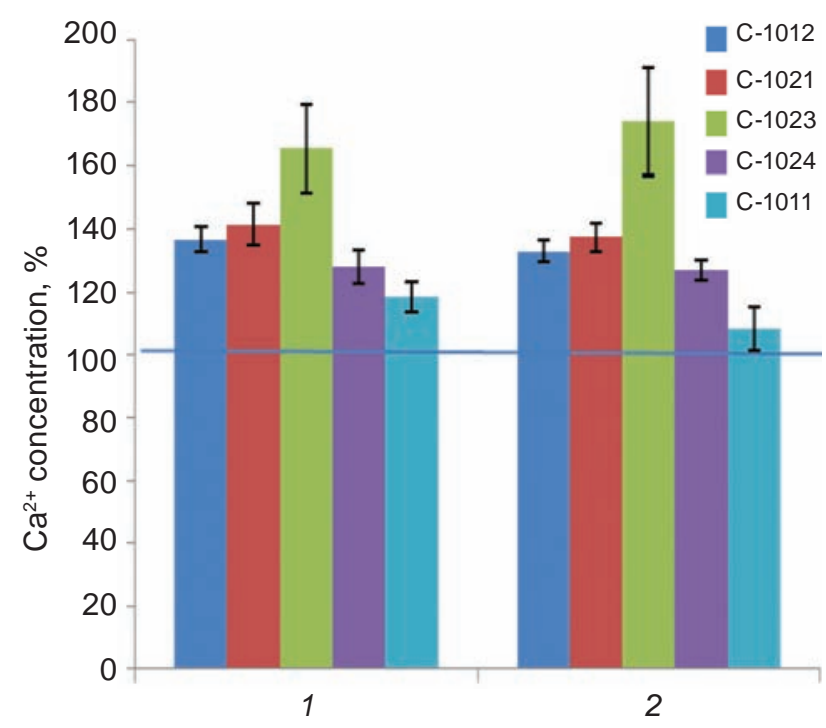

Fig. 5. $\left[\mathrm{Ca}^{2+}\right]_{m}$ values after 5 min mitochondria incubation in $\mathrm{Mg}^{2+}$,ATP-containing medium without (control $=100 \%)$ or with $10 \mu \mathrm{M}$ calix[4]arenes in the absence of exogenous $\mathrm{Ca}^{2+}$ (1) and $\left[\mathrm{Ca}^{2+}\right]_{m}$ values after next 5 min mitochondria incubation in the presence of $100 \mu M \mathrm{Ca}^{2+}(2) ;(M \pm m, n=4-5)$ 
C-1012, C-1021, C-1023 and increased with C-1011 (Fig. 6, 7). Changes of mitochondrial volume may strongly modulate mitochondrial physiology.

Thus, we have shown that a short-term incubation (5-10 min) of mitochondria in the presence of calix[4]arenes $(10 \mu \mathrm{M})$, which contain from two to four chalcone amide groups, increased the level of mitochondria membranes polarization, ionized $\mathrm{Ca}$ concentration in the matrix and have different effects on the mitochondrial volume.

It is known that mitochondria are the major site of ATP syntheses. The last does not take place without electrical potential across the mitochondrial inner membrane which is generated by the elec-

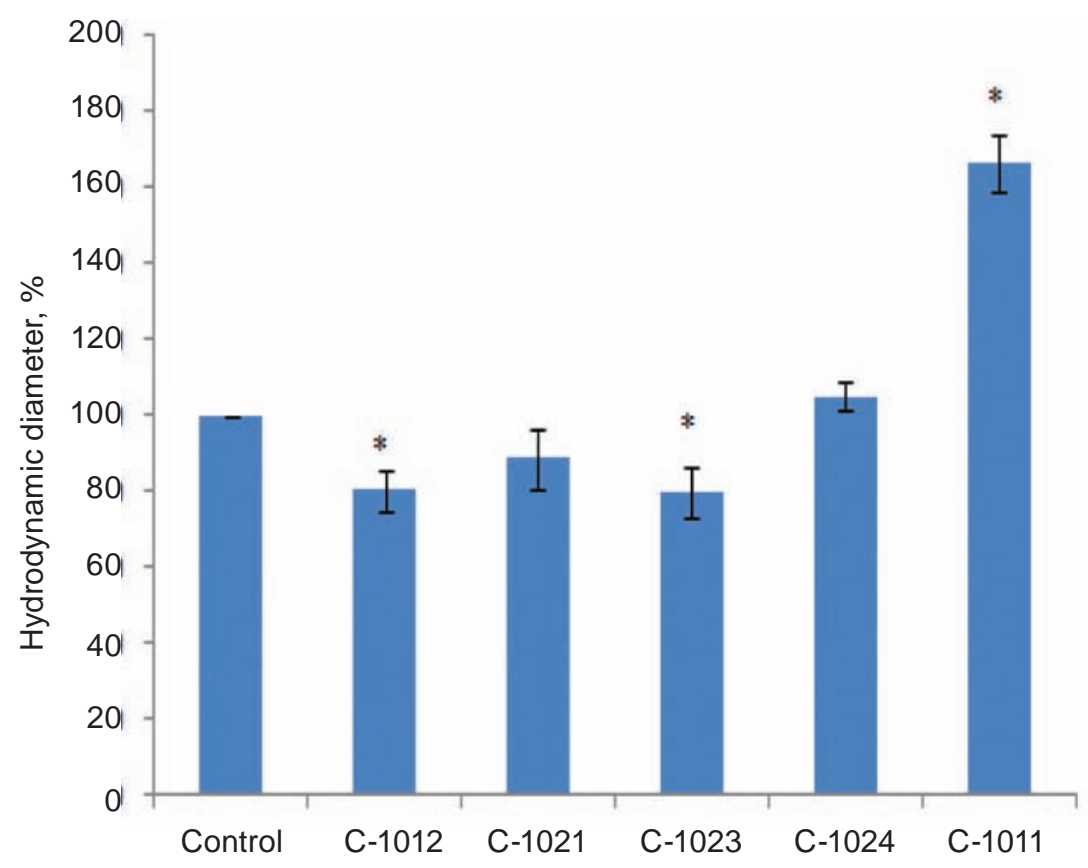

Fig. 6. The average hydrodynamic diameter of isolated mitochondria at incubation with calix[4]arenes $C-1012, C-1021, C-1023$ and $C$-1011 in $\mathrm{Mg}^{2+}$-containing medium $(M \pm m, n=5, P<0.05)$

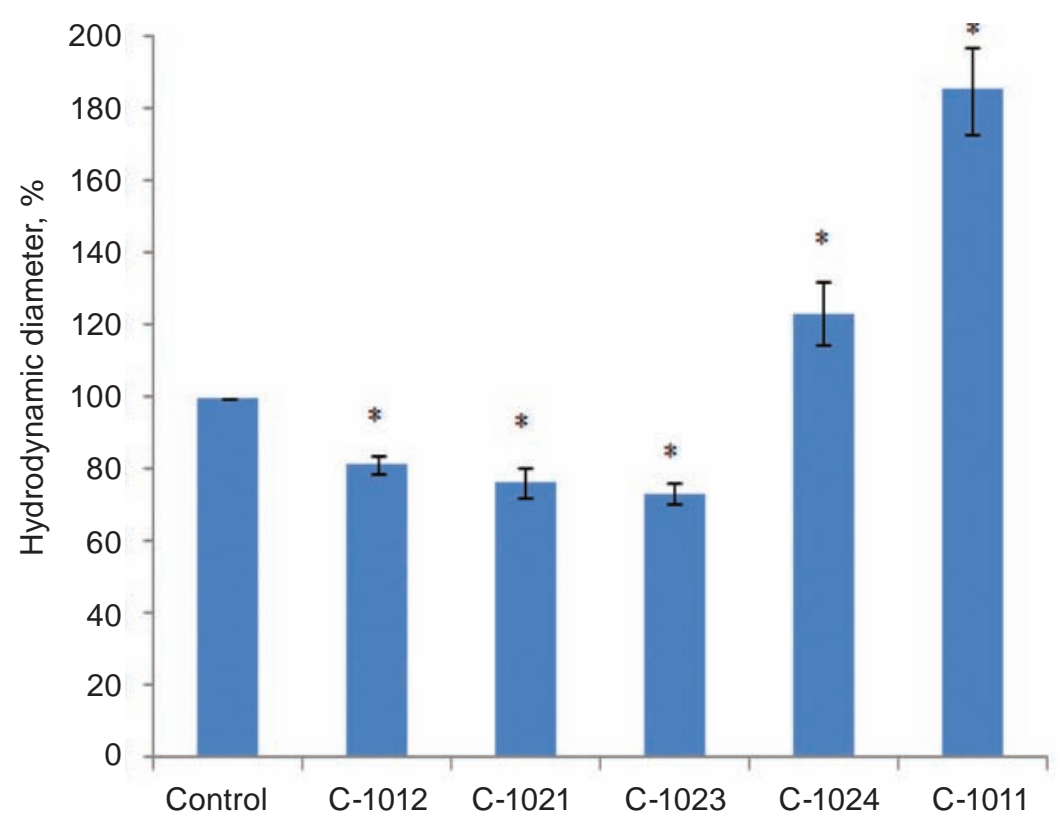

Fig. 7. The average hydrodynamic diameter of isolated mitochondria at incubation with calix[4]arenes C-1012, $C$-1021, C-1023 and C-1011 in $\mathrm{Mg}^{2+}$,ATP-containing medium $(M \pm m, n=5, P<0.05)$ 
tron transport chain [29]. On the other hand, mitochondria play an important role in the occurrence of pathological conditions by producing excessive reactive oxygen species (ROS) thereby damaging cellular components and initiating cell death [30]. It was shown that the generation of high mitochondrial membrane potential is a condition known to generate excessive ROS [30]. Hyperpolarization of mitochondrial membranes (exceeding $140 \mathrm{mV}$ ) causes an exponential increase in ROS generation [31, 32]. At the same time, in the case of mitochondrial disorders associated with the dysfunctions of the respiratory chain components, lower $\Delta \psi$ and decreased activity of the respiratory chain is observed with a simultaneous increase in ROS production [33]. ROS generated in the mitochondria can freely cross mitochondrial membranes or exit via mitochondrial channels such as VDAC and, once released, can cause oxidative damage throughout the cell [30]. It was suggested that induction of apoptosis could involve: excessive calcium release, transient hyperpolarization of $\Delta \Psi_{\mathrm{m}}$ and a burst in the production of ROS [30].

Mitochondria are central hubs for intrinsic apoptotic pathways that are activated by cellular stress and injury, and as a consequence, cancers often have defects in these pathways [34]. Chalcones and dihydrochalcones are intermediates in the biosynthesis of flavonoids and isoflavonoids in plants. These compounds are widely investigated for their anticancer activities [35]. Cytotoxic activity of hydroxychalcones is likely because of their ability to uncouple mitochondria [35, 36]. It was also shown that apoptosis via mitochondrial pathways might lead to the reduction of the volume of myoma and myometrium and eventual relief of symptoms [37]. It is known that mitochondria membrane hyperpolarization is followed by the collapse of the membrane potential. So, calix[4]arene-induced mitochondria membrane hyperpolarization can be useful at studying the ways of unwanted cells disposal.

Acknowledgment. This work was supported by grants (N 0118U006093 and N 0115U003638) from the target comprehensive program of fundamental researches of the National Academy of Sciences of Ukraine "Fundamental problems of creating new nanomaterials and nanotechnologies".

Conflict of interest. Authors have completed the Unified Conflicts of Interest form at http:// ukrbiochemjournal.org/wp-content/uploads/2018/12/ coi_disclosure.pdf and declare no conflict of interest.

\section{ЕФЕКТИ КАЛІКС[4]АРЕН- ХАЛКОНАМІДІВ НА МІТОХОНДРІЇ MIOMETPIЯ}

\author{
С. Г. Шликов ${ }^{1 凶}$, А. М. Кушнарьова-Вакал ${ }^{1}$, \\ А. В. Силенко, Л. Г. Бабіч ${ }^{1}$ О. Ю. Чуніхін ${ }^{1}$, \\ О. А. Єсипенко ${ }^{2}$ В. I. Кальченко 2 , \\ C. O. Костерін ${ }^{1}$
}

${ }^{1}$ Інститут біохімії ім. О. В. Палладіна
НАН України, Київ;
${ }^{凶}$ e-mail: sshlykov@biochem.kiev.ua;

${ }^{2}$ Інститут органічної хімії НАН України, Київ

Мітохондрії відіграють ключову роль у найважливіших функціях клітин. Каліксарени це супрамолекулярні сполуки, які широко застосовуються в біоорганічній хімії та біохімії. Мета цієї роботи - дослідити ефекти калікс[4]аренів, які містять у своїй структурі дві (C-1012 і C-1021), три (С-1023 і С-1024) та чотири (С-1011) халконамідні групи, на поляризацію мембран мітохондрій міометрія, на рівень іонізованого Са в матриксі цих органел та на середній гідродинамічний діаметр мітохондрій. Встановлено, що інкубація пермеабілізованих клітин міометрія 3 калікс[4]аренами, що містять від двох до чотирьох халконамідних груп супроводжується збільшенням рівня поляризації мембран мітохондрій міометрія. Відомо, що акумуляція $\mathrm{Ca}^{2+}$ в мітохондріях $\epsilon$ потенціалзалежним процесом. Отже, подальші експерименти було спрямовано на дослідження впливу калікс[4]аренхалконамідів на концентрацію іонізованого Са в матриксі мітохондрій $\left(\left[\mathrm{Ca}^{2+}\right]_{\mathrm{m}}\right)$. Усі досліджувані калікс[4]арени збільшували рівень іонізованого Са в матриксі як за відсутності, так і в присутності екзогенного $\mathrm{Ca}^{2+}$. Маємо підкреслити, що значення $\left[\mathrm{Ca}^{2+}\right]_{\mathrm{m}}$ (за відсутності екзогенного $\mathrm{Ca}^{2+}$ ) були вище за умов інкубації мітохондрій у $\left(\mathrm{Mg}^{2+}\right)$-, ніж у $\left(\mathrm{Mg}^{2+}, \mathrm{ATP}\right)$-вмісному середовищі. Також було встановлено, що інкубація ізольованих мітохондрій $з$ досліджуваними калікс[4]аренами супроводжується зміною об'єму мітохондрій: середній гідродинамічний діаметр мітохондрій зменшується за інкубації в присутності C-1012, С-1021, С-1023 та збільшується у разі з С-1011. Зауважимо, зміна об'єму мітохондрій може суттєво позначитись на фізіології цих органел. Таким чином, ми показали, що короткотермінова інкубація $(5 \mathrm{xв})$ мітохондрій у присутності калікс[4]аренів (10 мкМ), які в сво- 
ій структурі містять від двох до чотирьох халконамідних груп, збільшує рівень поляризації мембран мітохондрій, рівень іонізованого Са в матриксі та модулює об’єм мітохондрій.

К л ю ч о в і с лов а: міометрій, мітохондрії, $\left[\mathrm{Ca}^{2+}\right]_{\mathrm{m}}, \mathrm{Mg}^{2+}$, АТР, калікс[4]аренхалконаміди.

\section{References}

1. Babich LG, Shlykov SG, Boyko VI, Kliachina MA, Kosterin SA. Calix[4]arenes C-136 and C-137 hyperpolarize myometrium mitochondria membranes. Bioorg Khim. 2013; 39(6): 728-735. (In Russian).

2. Molecular Basis for Mitochondrial Signaling. Cham: "Springer International Publishing," 2017.

3. DeLuca HF, Engstrom GW. Calcium uptake by rat kidney mitochondria. Proc Natl Acad Sci USA. 1961; 47: 1744-1750.

4. Filadi R, Theurey P, Rossi A, Fedeli C, Pizzo P. Mitochondrial $\mathrm{Ca}^{2+}$ Handling and Behind: The Importance of Being in Contact with Other Organelles. In: Biological and Medical Physics, Biomedical Engineering. 2017: 3-39.

5. Babich LH, Shlykov SH, Kosterin SO. Ca ion transport in smooth muscle mitochondria. $\mathrm{Ukr}$ Biochem J. 2014; 86(6): 18-30. (In Ukrainian).

6. Dedkova EN, Blatter LA. Calcium signaling in cardiac mitochondria. J Mol Cell Cardiol. 2013; 58: $125-133$.

7. Williams GS, Boyman L, Chikando AC, Khairallah RJ, Lederer WJ. Mitochondrial calcium uptake. Proc Natl Acad Sci USA. 2013; 110(26): 10479-10486.

8. Rodik R, Boiko V, Danylyuk O, Suwinska K, Tsymbal I, Slinchenko N, Babich L, Shlykov S, Kosterin S, Lipkowski J, Kalchenko V. Calix[4]arenesulfonylamidines. Synthesis, structure and influence on $\mathrm{Mg}^{2+}$, ATP-dependent calcium pumps. Tetrahedron Lett. 2005; 46(43): 7459-7462.

9. Shlykov SH, Babich LH, Slichenko NM, Rodik RV, Boyko VI, Kal'chenko VI, Kosterin SO. Calixarene C-91 stimulates $\mathrm{Ca}^{2+}$ accumulation in the myometrium mitochondria. Ukr Biokhim Zhurn. 2007; 79(4): 28-33. (In Ukrainian).

10. Babich LG, Shlykov SG, Kushnarova AM, Esypenko OA, Kosterin SO. Calix[4]arene chalcone amides - The nanosize modulators of polarization of mitochondrial membranes and content of the ionized $\mathrm{Ca}$ in them. Nanosistemi, Nanomater Nanotehnologii. 2017; 15(1): 193202.

11. Shetty D, Jahovic I, Raya J, Asfari Z, Olsen JC, Trabolsi A. Porous polycalix[4]arenes for fast and efficient removal of organic micropollutants from water. ACS Appl Mater Interfaces. 2018; 10(3): 2976-2981.

12. Orlikova B, Tasdemir D, Golais F, Dicato M, Diederich M. Dietary chalcones with chemopreventive and chemotherapeutic potential. Genes Nutr. 2011; 6(2): 125-147.

13. León-González AJ, Acero N, MuñozMingarro D, Navarro I, Martín-Cordero C. Chalcones as promising lead compounds on cancer therapy. Curr Med Chem. 2015; 22(30): 3407-3425.

14. Mahapatra DK, Bharti SK. Therapeutic potential of chalcones as cardiovascular agents. Life Sci. 2016; 148: 154-172.

15. Zhang S, Li T, Zhang Y, Xu H, Li Y, Zi X, Yu H, Li J, Jin CY, Liu HM. A new brominated chalcone derivative suppresses the growth of gastric cancer cells in vitro and in vivo involving ROS mediated up-regulation of DR5 and 4 expression and apoptosis. Toxicol Appl Pharmacol. 2016; 309: 77-86.

16. Zhou B, Xing C. Diverse molecular targets for chalcones with varied bioactivities. Med Chem (Los Angeles). 2015; 5(8): 388-404.

17. Nimse SB, Kim T. Biological applications of functionalized calixarenes. Chem Soc Rev. 2013; 42(1): 366-386.

18. Iwamoto K, Shinkai S. Synthesis and ion selectivity of all conformational isomers of tetrakis[(ethoxycarbonyl)methoxy]calix[4]arene. J Org Chem. 1992; 57(26): 7066-7073.

19. Klyachina MA, Boyko VI, Yakovenko AV, Babich LG, Shlykov SG, Kosterin SO, Khilya VP, Kalchenko VI. Calix[4]arene N-chalconeamides: synthesis and influence on $\mathrm{Mg}^{2+}$,ATP-dependent $\mathrm{Ca}^{2+}$ accumulation in the smooth muscle subcellular structures. J Incl Phenom Macrocycl Chem. 2008; 60(1-2): 131137.

20. Kosterin SA, Bratkova NF, Kurskiy MD. The role of sarcolemma and mitochondria in calciumdependent control of myometrium relaxation. Biokhimiia (Mosc). 1985; 50(8): 1350-1361. (In Russian). 
21. Bradford MM. A rapid and sensitive method for the quantitation of microgram quantities of protein utilizing the principle of protein-dye binding. Anal Biochem. 1976; 72: 248-254.

22. Mollard P, Mironneau J, Amedee T, Mironneau C. Electrophysiological characterization of single pregnant rat myometrial cells in short-term primary culture. Am J Physiol. 1986; 250(1 Pt 1): C47-C54.

23. Grynkiewicz G, Poenie M, Tsien RY. A new generation of $\mathrm{Ca}^{2+}$ indicators with greatly improved fluorescence properties. $J$ Biol Chem. 1985; 260(6): 3440-3450.

24. Antonenko YN, Avetisyan AV, Cherepanov DA, Knorre DA, Korshunova GA, Markova OV, Ojovan SM, Perevoshchikova IV, Pustovidko AV, Rokitskaya TI, Severina II, Simonyan RA, Smirnova EA, Sobko AA, Sumbatyan NV, Severin FF, Skulachev VP. Derivatives of rhodamine 19 as mild mitochondria-targeted cationic uncouplers. J Biol Chem. 2011; 286(20): 17831-17840.

25. Divakaruni AS, Brand MD. The regulation and physiology of mitochondrial proton leak. Physiology (Bethesda). 2011; 26(3): 192-205.

26. McCarron JG, Olson ML, Wilson C, Sandison ME, Chalmers S. Examining the role of mitochondria in $\mathrm{Ca}^{2+}$ signaling in native vascular smooth muscle. Microcirculation. 2013; 20(4): 317-329.

27. Babich LG, Shlykov SG, Borisova LA, Kosterin SA. Energy-dependent $\mathrm{Ca}^{2+}$-transport in intracellular smooth muscle structures. Biokhimiia (Mosc). 1994; 59(8): 1218-1229. (In Russian).

28. Babich LG, Shlykov SG, Kushnarova AM, Kosterin SO. $\mathrm{Ca}^{2+}$-dependent regulation of the $\mathrm{Ca}^{2+}$ concentration in the myometrium mitochondria. I. Trifluoperazine effects on mitochondria membranes polarization and $\left[\mathrm{Ca}^{2+}\right]_{\mathrm{m}}$. Ukr Biochem J. 2016; 88(4): 5-11.
29. Kaim G, Dimroth P. ATP synthesis by F-type ATP synthase is obligatorily dependent on the transmembrane voltage. EMBO J. 1999; 18(15): 4118-4127.

30. Sanderson TH, Reynolds CA, Kumar R, Przyklenk K, Hüttemann M. Molecular mechanisms of ischemia-reperfusion injury in brain: pivotal role of the mitochondrial membrane potential in reactive oxygen species generation. Mol Neurobiol. 2013; 47(1): 9-23.

31. Starkov AA, Fiskum G. Regulation of brain mitochondrial $\mathrm{H}_{2} \mathrm{O}_{2}$ production by membrane potential and NAD(P)H redox state. J Neurochem. 2003; 86(5): 1101-1107.

32. Liu SS. Mitochondrial Q cycle-derived superoxide and chemiosmotic bioenergetics. Ann N Y Acad Sci. 2010; 1201(1): 84-95.

33. Suski JM, Lebiedzinska M, Bonora M, Pinton P, Duszynski J, Wieckowski MR. Relation between mitochondrial membrane potential and ROS formation. Methods Mol Biol. 2012; 810: 183205.

34. Hockenbery DM. Targeting mitochondria for cancer therapy. Environ Mol Mutagen. 2010; 51(5): 476-489.

35. Gutierrez RMP, Muniz-Ramirez A, Sauceda JV. Review: The potential of chalcones as a source of drugs. African J Pharm Pharmacol. 2015; 9(8): 237-257.

36. Sabzevari O, Galati G, Moridani MY, Siraki A, O'Brien PJ. Molecular cytotoxic mechanisms of anticancer hydroxychalcones. Chem Biol Interact. 2004; 148(1-2): 57-67.

37. Cheng ZP, Tao $X$, Gong J, Dai $\mathrm{H}$, Hu LP, Yang WH. Early-stage morphological observations of myoma and myometrium after laparoscopic uterine artery occlusion treatment. Eur J Obstet Gynecol Reprod Biol. 2009; 145(1): 113-116. 